\title{
Teknologi Pupuk Slow Release Sebagai Alternatif Pemupukan Ramah Lingkungan: \\ Penggunaan Arang Kayu
}

Danner Sagala

Universitas Prof. Dr. Hazairin, SH

J1. Jend. A. Yani No. 1 Bengkulu, Indonesia

Email: danner_10@unihaz.ac.id

\begin{abstract}
Abstrak
Penggunaan teknologi pertanian harus bersifat lestari atau atau ramah lingkungan. Keuntungan penggunaan teknologi ramah lingkungan adalah efisiensi dan keberlanjutan. Salah satu teknologi pemupukan yang potensial dikembangkan adalah pupuk slow release. Pupuk slow release menyediakan unsur hara secara gradual untuk waktu yang lama. Namun, pupuk slow release kebanyakan dibuat dengan menggunakan pembungkus (coating) pada butir pupuk yang sebenarnya dapat juga dicurigai sebagai perusak tanah. Oleh sebab itu pembuatan pupuk slow release menggunakan arang kayu menjadi salah satu alternatif. Karena selain menjadi penyimpan hara untuk pupuk slow release, arang kayu ini dipastikan tidak menggunakan pembungkus (coat), jika terdokomposisi akan menambah bahan organic tanah, dapat mendekomposisi minyak pada tanah dan menyerap logam berat
\end{abstract}

\section{PENDAHULUAN}

Kesalahan pengelolaan pupuk, apakah itu pupuk organik maupun inorganik, yang digunakan dalam pertanian menyebabkan ketidakefisienan yang berdampak pada kehilangan keuntungan petani dan kekurangan sumberdaya, dan menyebabkan kerusakan lingkungan yang potensial. Pupuk yang diberikan pada tanaman melebihi kemampuan serap tanaman pada suatu titik waktu menyebabkan terbuangnya unsur hara yang terkandung dalam pupuk khususnya unsure hara mobile. Namun, tidak hanya pada pupuk yang mengandung unsur hara yang bersifat mobile dan volatile seperti nitrogen, namun juga pada pupuk yang non-mobile seperti fosfor. Kehilangan unsur hara dalam pupuk dapat terjadi melalui pencucian (leaching) akibat aliran permukaan dan perkolasi, dan menguap. Oleh karena itu, penggunaan pupuk seharusnya sesuai dengan kebutuhan, sesuai waktu dan berimbang sehingga kehilangan pupuk dapat diperkecil. Salah satu kerusakan lingkungan akibat penggunaan pupuk yang tidak baik adalah terjadinya polusi air. Pencucian hara yang berlebih akibat aliran permukaan akan menyebabkan akumulasi senyawa kimia pada sungai, danau atau penampungan air lainnya.

Cara menyitat: Sagala, Danner, 2018. “Teknologi Pupuk Slow Release Sebagai Alternatif Pemupukan Ramah Lingkungan: Penggunaan Arang Kayu”. INA-Rxiv. February 10. osf.io/preprints/inarxiv/xnh9u 
Salah satu metode mitigasi yang efektif adalah mengembangkan pupuk slow release. Pupuk slow release menyediakan unsur hara secara gradual untuk waktu yang lama. Penelitian di bidang pertanian akhir-akhir ini telah berhasil mengembangkan berbagai macam pupuk yang keluar (release) secara perlahan-lahan yang salah satunya menggunakan arang kayu sebagai media pupuk slow release. Namun, penelitian pemanfaatan arang kayu sebagai media pupuk slow release masih terbatas yang diantaranya akan dirangkum dalam paper ini.

Paper ini akan membahas mengenai pentingnya pupuk slow release, arang kayu sebagai media amandemen tanah dan penyimpanan hara, dan arang kayu sebagai pembersih lingkungan.

\section{PUPUK SLOW RELEASE}

Pencucian hara dalam tanah dengan kapasitas daya simpan yang rendah menyebabkan rendahnya produksi tanaman dan terkontaminasinya air tanah. Oleh karena itu dibutuhkan teknologi pupuk yang memiliki kelarutan yang rendah namun dapat menyediakan hara pada tanaman. Pupuk slow release merupakan pupuk dengan kelarutan hara yang rendah dan dapat menyediakan hara secara gradual (terus-menerus) untuk waktu yang panjang. Dengan low release, efisiensi penyerapan hara akan tinggi dan kehilangan hara akibat pencucian akan rendah.

Hasil penelitian Xiaoyu et al. (2013) terhadap penggunaan pupuk slow release menyebabkan release hara dari pupuk sangat lambat. Data pada Gambar 1C memperlihatkan bahwa urea yang dibuat menjadi slow release (S-Urea) bergerak lebih lambat dibandingkan dengan perlakuan pupuk urea yang lain dimana pupuk urea tanpa perlakuan bergerak (release) paling cepat dibandingkan urea pada berbagai perlakuan yang lain. Kemudian perlakuan persentase S-Urea menunjukkan bahwa semakin tinggi persentasi bentonit dalam S-Urea maka semakin lama release hara dari pupuk tersebut (Gambar 1D).

Data Gambar 1 A dan B menunjukkan bahwa release hara yang lambat dari pupuk slow release menyebabkan kehilangan hara yang rendah. Kehilangan hara pada hari pertama perlakuan pupuk urea tanpa perlakuan mencapai $53 \mathrm{mg}$ (urea) dan $30 \mathrm{mg}$ (Nitrogen). Sedangkan pada hari pertama pemberian urea slow release, kehilangan hara hanya $15 \mathrm{mg}$ (urea) dan $10 \mathrm{mg}$ (Nitrogen). Penggunaan pupuk slow release dapat mencegah kehilangan hara sebanyak 2-3 kali lipat.

Release yang lama dan karakteristik efisiensi yang tinggi, pupuk ini dapat menghemat pupuk dan tenaga kerja pemupuk, mengurangi kehilangan hara dan polusi, menyederhanakan praktek

Cara menyitat: Sagala, Danner, 2018. “Teknologi Pupuk Slow Release Sebagai Alternatif Pemupukan Ramah Lingkungan: Penggunaan Arang Kayu”. INA-Rxiv. February 10. osf.io/preprints/inarxiv/xnh9u 
budidaya tanaman. Penghematan dan penyederhanaan ini akhirnya dapat meningkatkan pendapatan petani. Penggunaan pupuk slow release dapat menurunkan volatilisasi gas ammonia dan emisi $\mathrm{N}_{2} \mathrm{O}$, sehingga sangat signifikan dalam melindungi lingkungan dan merupakan pertanian bebas polusi.

Perlambatan release hara dari pupuk low release ini disebabkan oleh ikatan atau pembungkusan terhadap butir pupuk. Perlambatan release oleh pembungkus ini dikendalikan oleh difusi melalui bungkus yang dapat berupa sulfur, polyetilen, superfosfat. Namun pembungkus dengan cara ini membutuhkan biaya yang tinggi (Xiaoyu et al., 2013). Selain itu Khan et al. (2008) mengembangkan pupuk slow release dengan menggunakan arang kayu sebagai media/pembungkus. Mengenai ini akan dibahas dalam bab berikutnya.
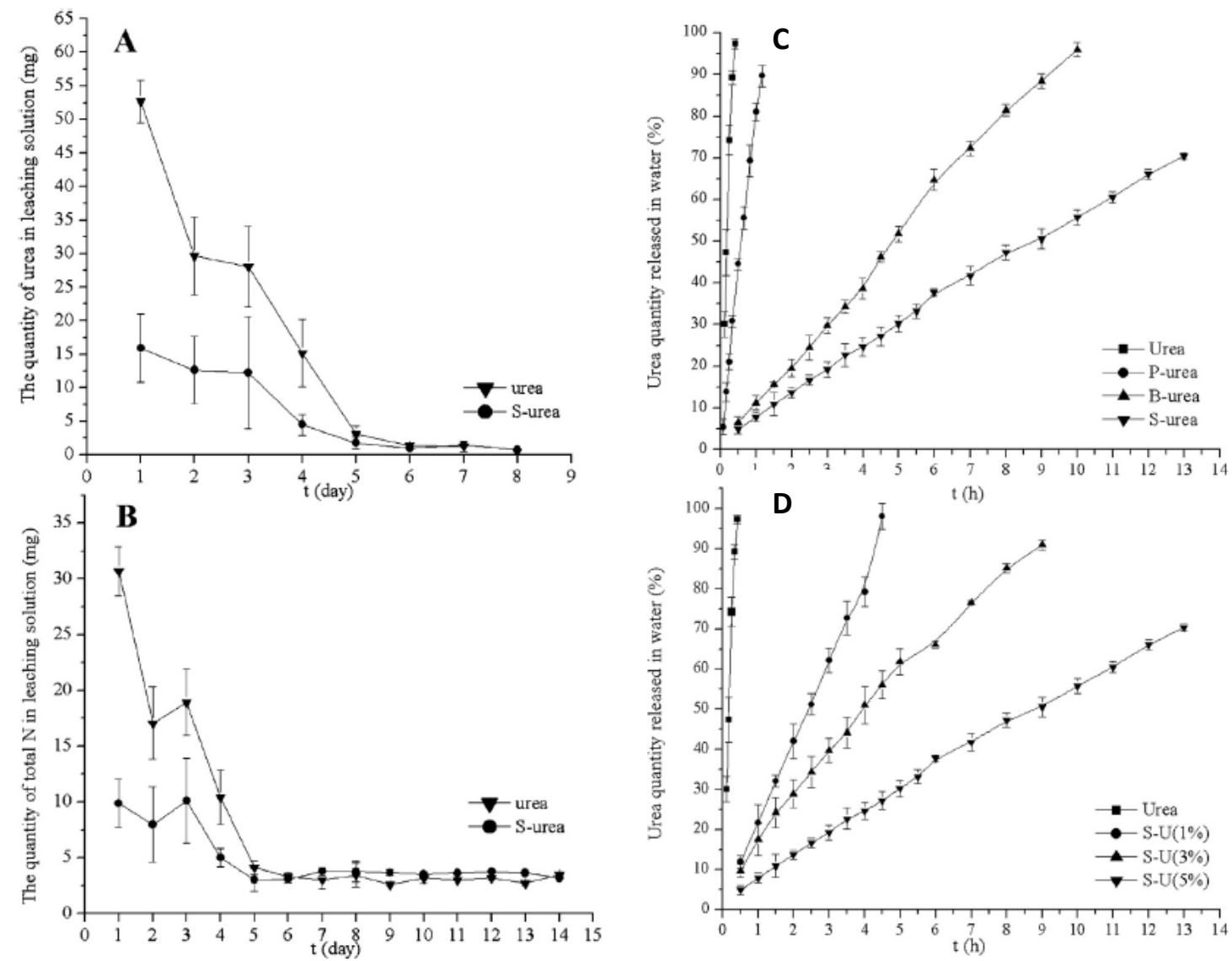

Gambar 1. Pencucian hara (A dan B) dan release hara dari pupuk (C dan D)

\section{ARANG MEDIA PENYIMPAN HARA PUPUK LOW RELEASE}

Khan et al. (2008) menemukan bahwa penggunaan arang sebagai media hara sangat baik digunakan sebagai pengganti pembungkus (coat) pupuk low release. Arang yang berasal dari kayu diperkaya dengan hara dan dibentuk menjadi pellet. Penggunaan arang ini sebenarnya

Cara menyitat: Sagala, Danner, 2018. "Teknologi Pupuk Slow Release Sebagai Alternatif Pemupukan Ramah Lingkungan: Penggunaan Arang Kayu”. INA-Rxiv. February 10. osf.io/preprints/inarxiv/xnh9u 
telah lama digunakan sebagai bahan amandemen tanah seperti yang dilakukan oleh Matsumoto (1999) menggunakan arang sekam batang kelapa.

Khan et al. (2008) menggunakan batang kayu Oak karena batang kayu ini lebih kuat dan tahan panas. Batang kayu oak yang kering angin dipotong-potong dan kemudian dikarbonasi pada $600^{\circ} \mathrm{C}$ selama 4 hari dalam tungku hingga menghasilkan arang yang porous. Kemudian arang dimasukkan dalam evaporator vakum rotary yang berisi larutan hara N:P:K (20:9:20) dengan hara mikro lalu diputar selama 24 jam pada suhu $100^{\circ} \mathrm{C}$ (Gambar 2 dan Gambar 3).

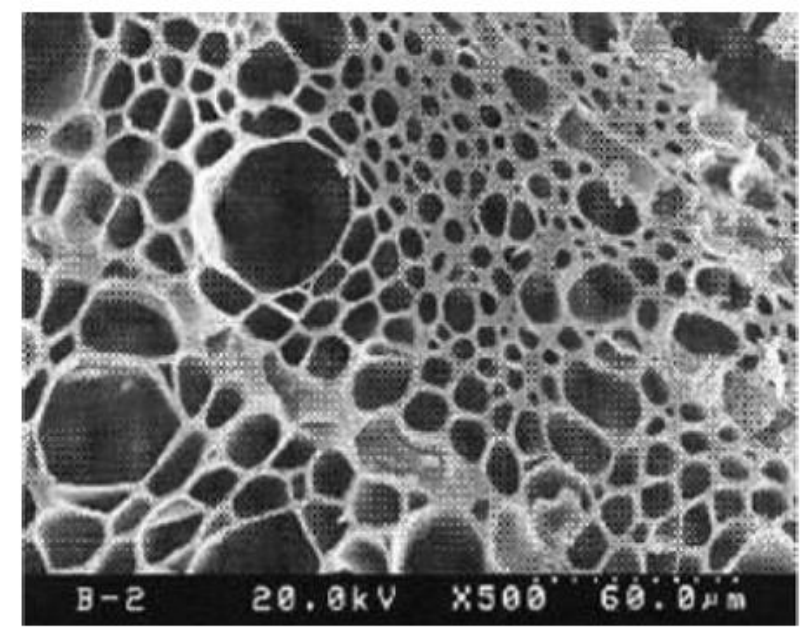

Gambar 2. Gambar mikro menggunakan SEM, Arang kayu oak yang dikarbonisasi pada suhu $600^{\circ} \mathrm{C}$
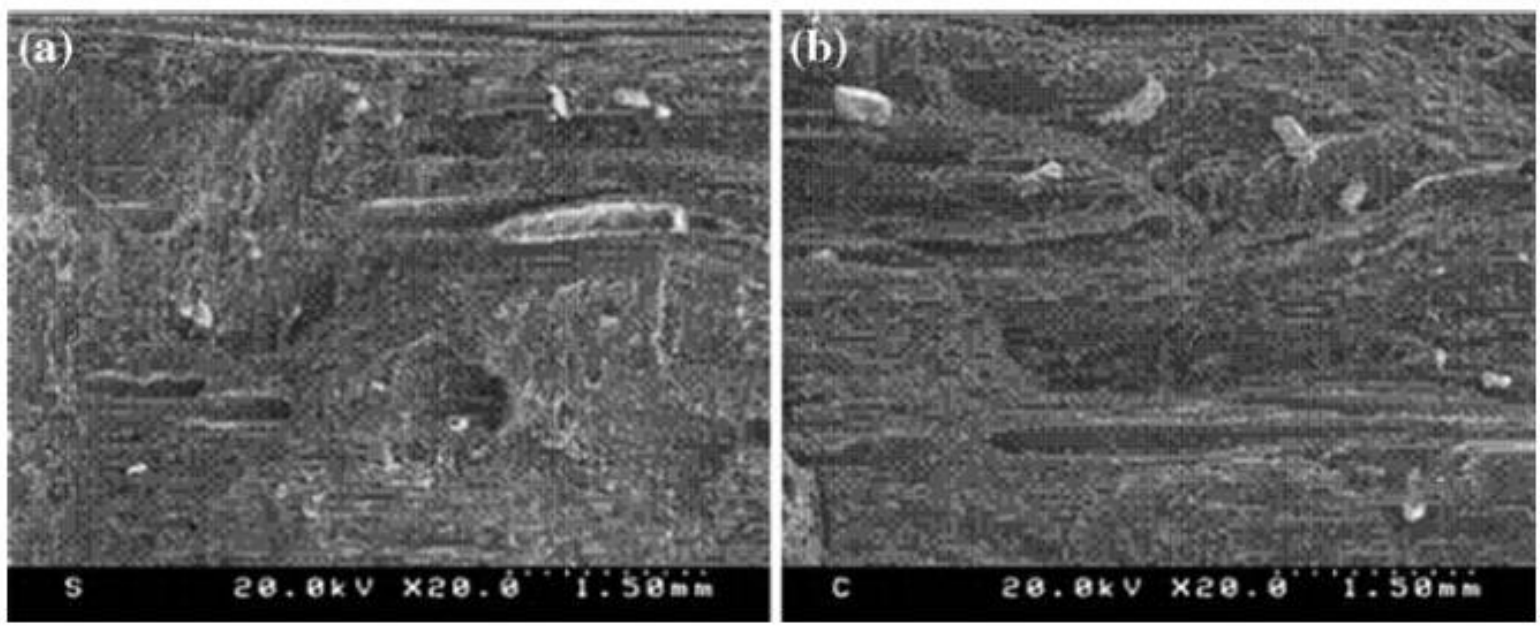

Gambar 3. Potongan membujur arang yang sudah diperkaya dengan hara

Cara menyitat: Sagala, Danner, 2018. "Teknologi Pupuk Slow Release Sebagai Alternatif Pemupukan Ramah Lingkungan: Penggunaan Arang Kayu”. INA-Rxiv. February 10. osf.io/preprints/inarxiv/xnh9u 

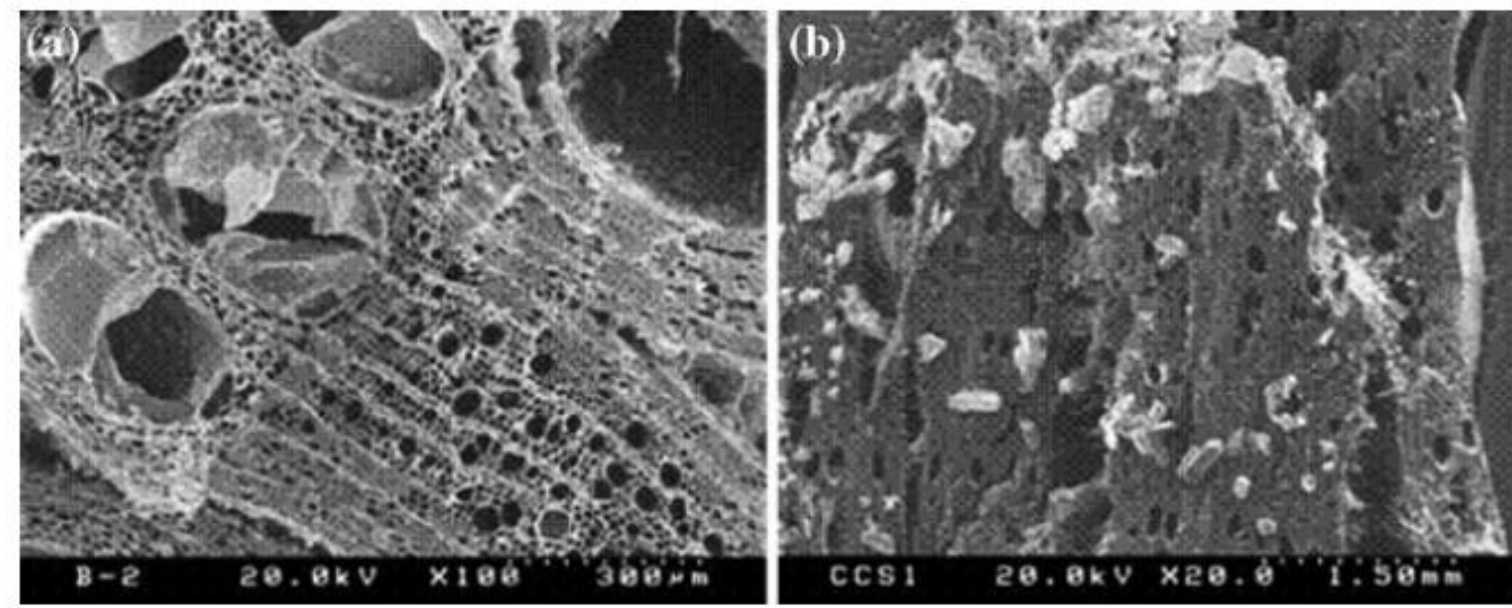

Gambar 4. Penampang melintang arang yang sudah diperkaya dengan hara
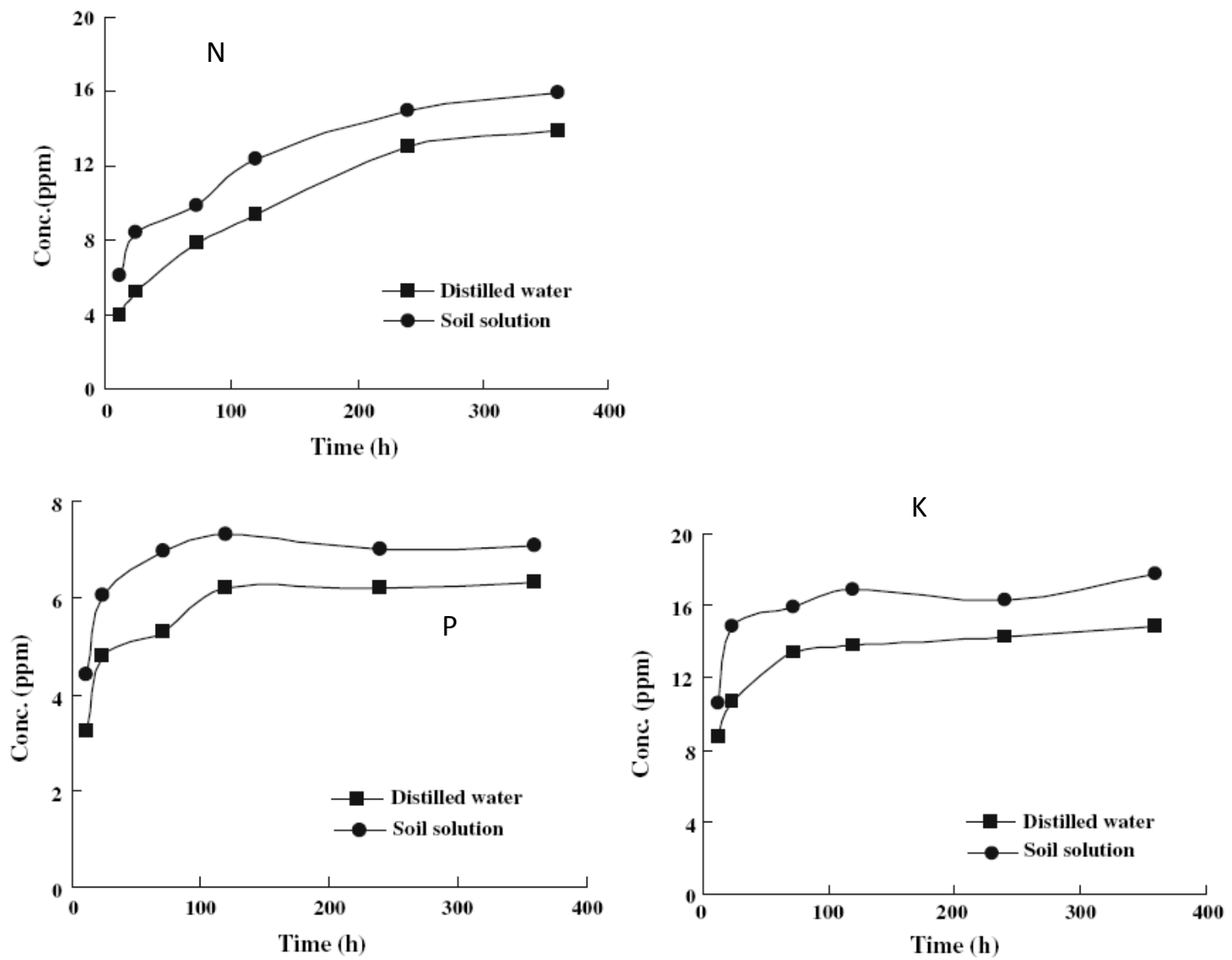

Gambar 5. Release hara N, P, K dari arang yang diperkaya

Cara menyitat: Sagala, Danner, 2018. "Teknologi Pupuk Slow Release Sebagai Alternatif Pemupukan Ramah Lingkungan: Penggunaan Arang Kayu”. INA-Rxiv. February 10. osf.io/preprints/inarxiv/xnh9u 

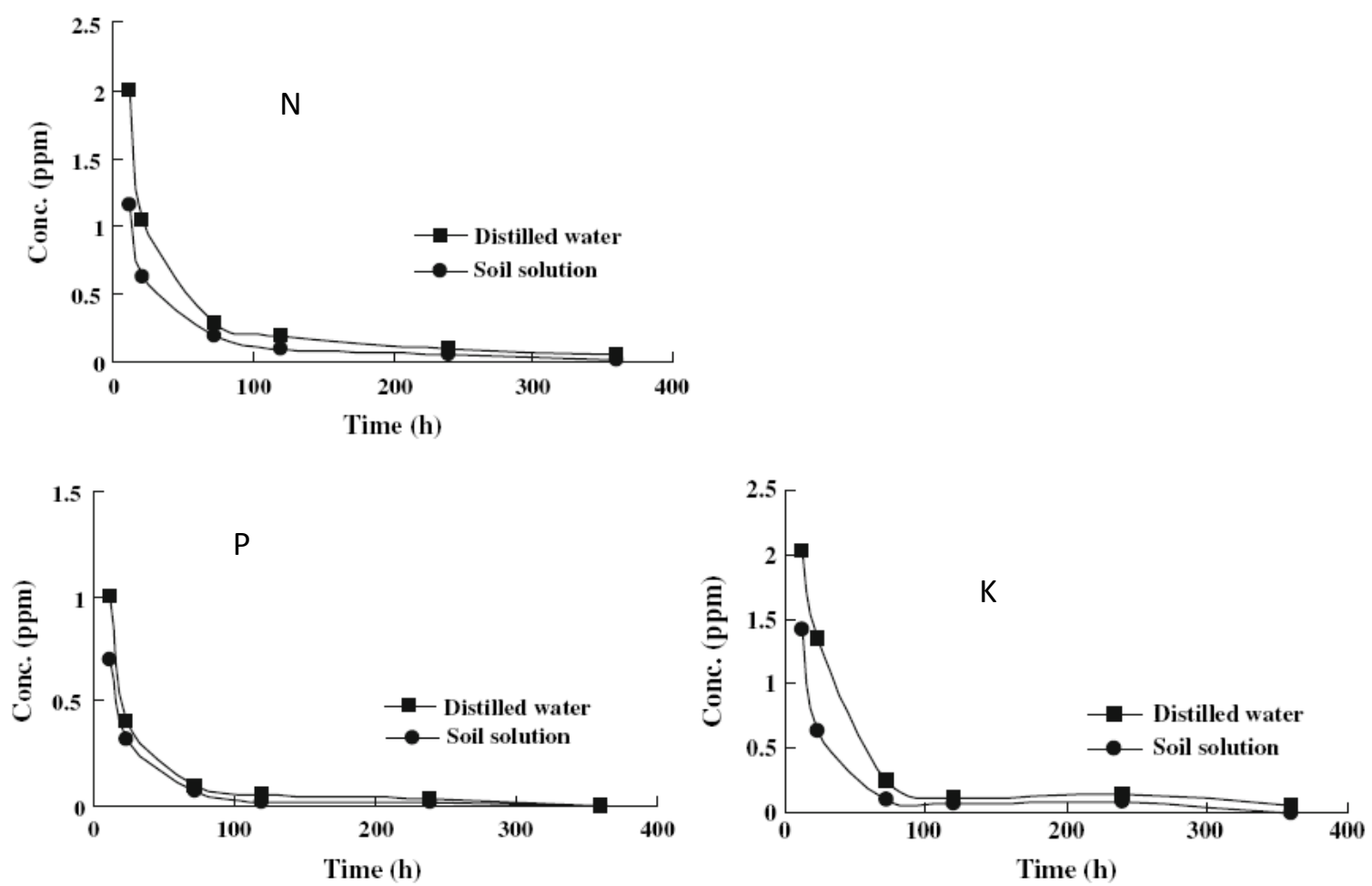

Gambar 6. Pencucian hara N, P, K dari arang yang diperkaya hara

Penelitian ini memiliki kelemahan dimana peneliti tidak membandingkan release dan kehilangan hara dari arang dan pupuk sehingga dengan data pada Gambar 5 dan 6 tidak dapat diambil kesimpulan mengenai perlambatan release. Namun, peneliti menyatakan bahwa arang yang diperkaya hara ini dapat berfungsi sebagai pupuk low release.

\section{ARANG KAYU SEBAGAI AMANDEMEN TANAH DAN PEMBERSIH LINGKUNGAN}

Selain sebagai media penyimpan hara untuk pupuk low release, penggunaan arang ini juga aman karena tidak mengandung bahan pembungkus yang bisa saja berbahaya. Keuntungan lain adalah terjadinya penambahan bahan organik yang berasal dari arang jika telah mengalami dekomposisi dan menjadi bahan amandemen tanah lainnya. Keuntungan lainnya, penelitian Matsumoto (1999) memperlihatkan bahwa penggunaan arang batang kelapa dapat mendekomposisi minyak pada tanah (Gambar 7)

Cara menyitat: Sagala, Danner, 2018. "Teknologi Pupuk Slow Release Sebagai Alternatif Pemupukan Ramah Lingkungan: Penggunaan Arang Kayu”. INA-Rxiv. February 10. osf.io/preprints/inarxiv/xnh9u 


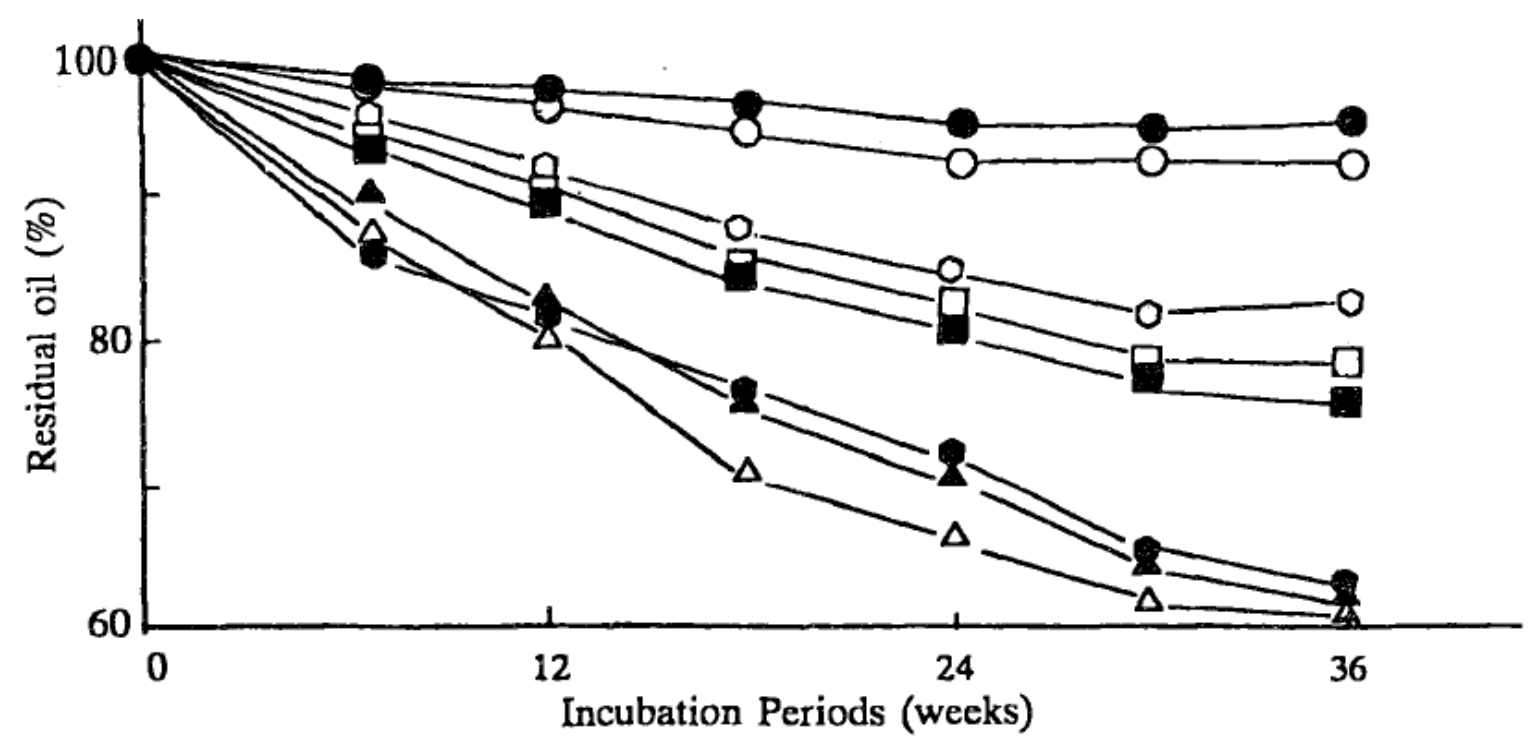

\begin{tabular}{|c|c|c|c|c|c|c|c|c|c|}
\hline \multirow{2}{*}{ Additives } & \multirow{2}{*}{ Rate of additives (g) } & \multicolumn{8}{|c|}{ The number of plot } \\
\hline & & 1 & 2 & 3 & 4 & 5 & 6 & 7 & 8 \\
\hline Oil-contaminated soil & 5,000 & 0 & 0 & 0 & 0 & 0 & 0 & 0 & $\mathrm{O}$ \\
\hline Bark compost & 500 & & & 0 & & 0 & 0 & 0 & $\mathrm{O}$ \\
\hline Inorganic nutrients & 50 & & & & 0 & 0 & 0 & 0 & \\
\hline Microporous materials & 250 & & & 0 & 0 & 0 & & & O \\
\hline Charcoal of coconut husk & 250 & & & & & & 0 & & \\
\hline Oil-decomposing bacteria & 10 & & & & & & & 0 & $\mathrm{O}$ \\
\hline Legends in Fig. 7 & & ? & 0 & E & $\square$ & $\Delta$ & $\Delta$ & 0 & $\bullet$ \\
\hline
\end{tabular}

Gambar 7. Arang batang kelapa sebagai amandemen tanah

Pulido et al. (1996) membuktikan bahwa arang kayu yang dikarbonisasi dapat menyerap logam berat dari air. Dengan kayu yang dikarbonasi pada $1000^{\circ} \mathrm{C}$, segera setelah dimasukkan ke dalam larutan langsung menyerap logam merkuri (Gambar 8). Oleh karena itu pengembangan pupuk slow release dengan memanfaatkan arang kayu sangat bermanfaat dalam menciptakan pertanian yang efisien, menguntungkan dan ramah lingkungan.

Cara menyitat: Sagala, Danner, 2018. "Teknologi Pupuk Slow Release Sebagai Alternatif Pemupukan Ramah Lingkungan: Penggunaan Arang Kayu”. INA-Rxiv. February 10. osf.io/preprints/inarxiv/xnh9u 


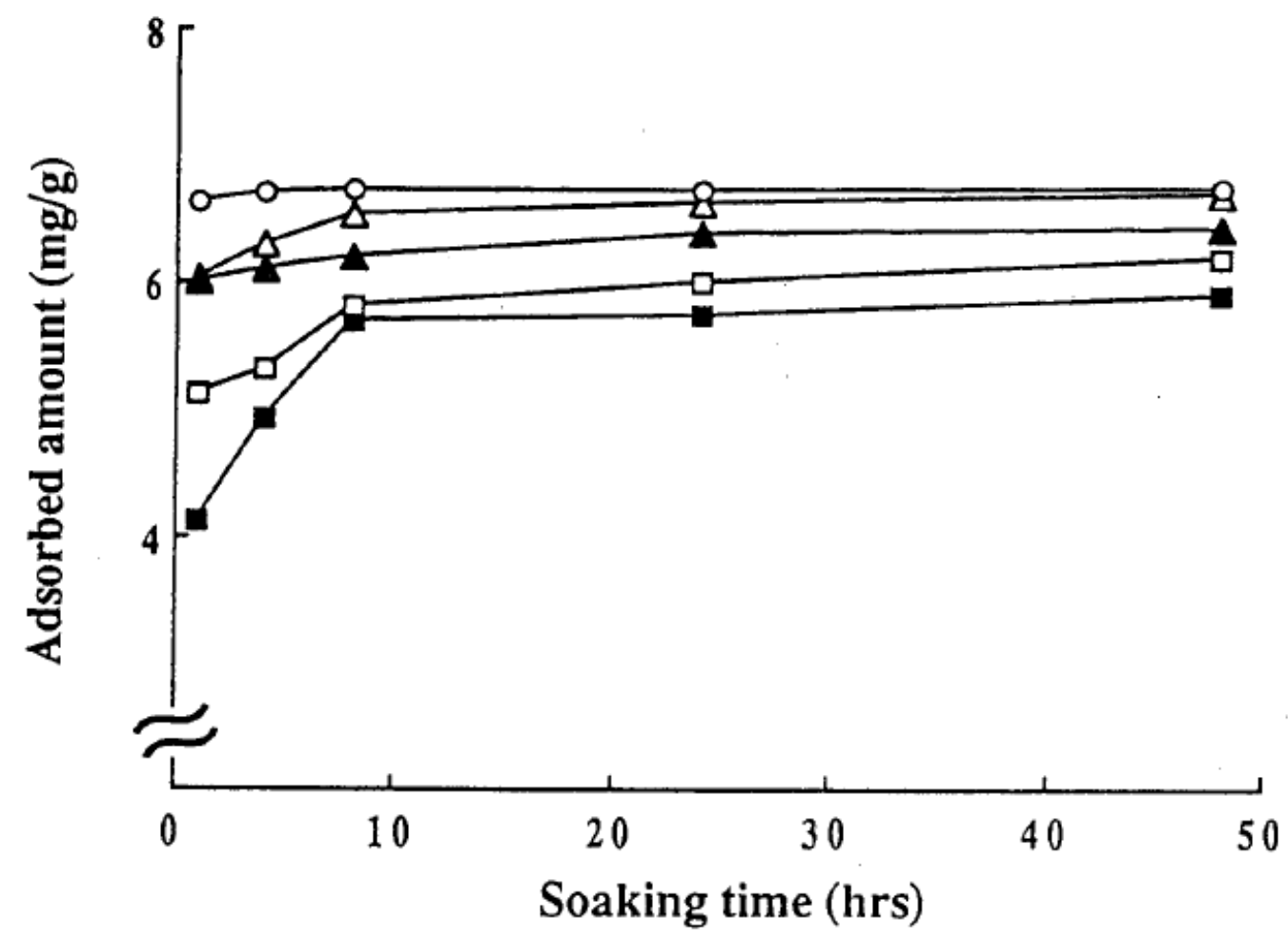

Relationship between soaking time and adsorbed amount of mercury in different adsorbent materials.

Note: One gram of each adsorbent material was mixed into $50 \mathrm{ml}$ of $50 \mathrm{ppm} \mathrm{HgCl}_{2}$ aqueous solutions.

\section{Legend: $\longrightarrow$ Wood powder ovedried at $105^{\circ} \mathrm{C}$ \\ $-\square-$ Wood powder carbonized at $200^{\circ} \mathrm{C}$ \\ $-\Delta-$ Wood powder carbonized at $600^{\circ} \mathrm{C}$ \\ $-\bigcirc-$ Wood powder carbonized at $1000^{\circ} \mathrm{C}$ \\ $-\Delta-$ Activated charcoal from coconut shell powder}

Gambar 8. Hubungan antara waktu perendaman bahan penyerap dengan jumlah merkuri yang diserap dengan berbagai macam penyerap

\section{PENUTUP}

Praktek pertanian dengan penggunaan pupuk secara besar-besaran dan tidak terkelola akan berdampak pada ketidak efisienan dan kerusakan lingkungan. Penggunaan pupuk yang terkontrol atau slow release menjadi salah satu upaya peningkatan efisiensi, peningkatan benefit petani dan menjaga kelestarian lingkungan. Pupuk slow release umumnya diperoleh dengan menggunakan pembungkus (coating) pada butir pupuk yang sebenarnya dapat juga dicurigai sebagai perusak tanah. Oleh sebab itu pembuatan pupuk slow release menggunakan arang kayu menjadi salah satu alternative. Karena selain menjadi penyimpan hara untuk pupuk 
low release, arang kayu ini dipastikan tidak menggunakan pembungkus (coat), jika terdokomposisi akan menambah bahan organic tanah, dapat mendekomposisi minyak pada tanah dan menyerap logam berat.

\section{DAFTAR PUSTAKA}

Khan, M.A., K. Kim, W. Mingzhi, B. Lim, W. Lee, J. Lee. 2008. Nutrient-impregnated charcoal: an environmentally friendly slow release fertilizer. Environmentalist. 28:231235.

Matsumoto, S. 1999. Fundamentals and Practices of Soil Bioremediation. Soil Sci. Plant Nutr. 45(1):237-251.

Pulido, L.L., S. Ishihara, Y. Imamura, T. Hata. 1996. Research and development of carbon composites from wood charcoal for environmental clean-up and their application. Wood Research. 83:43-46

Xiaoyu, N., W. Yuezin, W. Zhengyan, W. Lin, Q. Guannan, Y. Lixiang. 2013. A novel slowrelease urea fertilizer: physical and chemical analysis of its structure and study of its release mechanism. Biosystem Engineering. 115:274-282.

Cara menyitat: Sagala, Danner, 2018. "Teknologi Pupuk Slow Release Sebagai Alternatif Pemupukan Ramah Lingkungan: Penggunaan Arang Kayu”. INA-Rxiv. February 10. osf.io/preprints/inarxiv/xnh9u 